\title{
ПОЧАТОК I ЗАВЕРШЕННЯ НАВЧАЛЬНОГО РОКУ: ЗАРУБІЖНИЙ ДОСВІД
}

\author{
Інформація Національної академії педагогічних наук України на запит \\ Консультативної ради при Президентові України з питань сприяння \\ розвитку системи загальної середньої освіти
}

https://doi.org/10.37472/2707-305X-2021-3-2-14-1

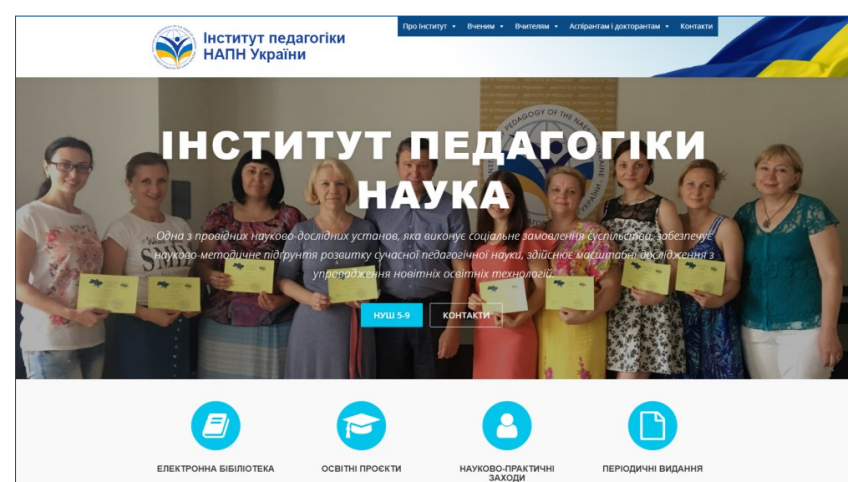

ТОПУзОВ Олег Михайлович

доктор педагогічних наук, профессор, дійсний член (академік) НАПН України, віце-президент Національної академії педагогічних наук України, директор Інституту педагогіки НАПН України, м. Київ, Україна

\section{ЛОКШИНА Олена Ігорівна}

доктор педагогічних наук, профресор, членкореспондент НАПН України, завідувач відділу порівняльної педагогіки Інституту педагогіки НАПН України, м. Київ, Україна

\section{ГЛУШКО Оксана Зіновіївна}

кандидат педагогічних наук, молодший науковий співробітник відділу порівняльної педагогіки Інституту педагогіки НАПН України, м. Київ, Україна

\section{ДЖУРИЛО Аліна Петрівна}

кандидат педагогічних наук, старший науковий співробітник відділу порівняльної педагогіки Iнституту педагогіки НАПН України, м. Київ, Україна

МАКСИМЕНКО Оксана Олексіївна кандидат педагогічних наук, науковий співробітник відділу порівняльної педагогіки Iнституту педагогіки НАПН України, м. Київ, Україна

\section{НІКОЛЬСЬКА Ніна Вікторівна}

кандидат педагогічних наук, старший науковий співробітник відділу порівняльної педагогіки Інституту педагогіки НАПН України, м. Київ, Україна

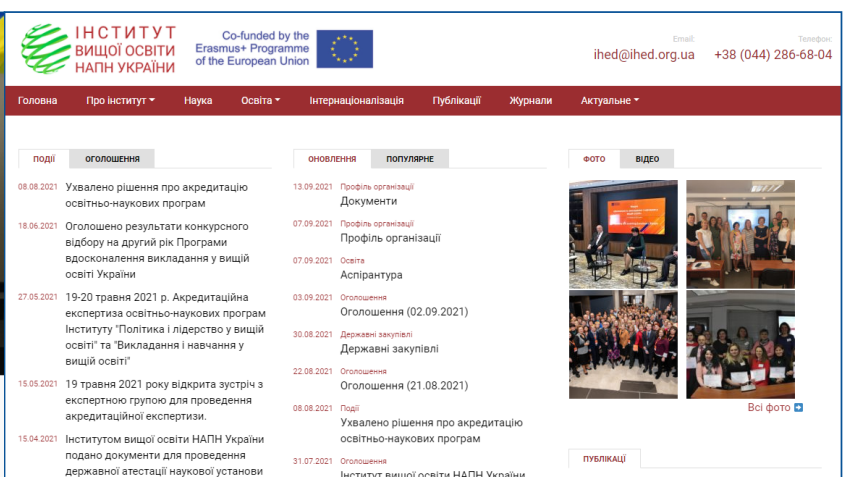

САУХ Петро Юрійович

доктор фрілософрських наук, професор, дійсний член (академік) НАПН України, академік-секретар Відділення вищої освіти Національної академії педагогічних наук України, м. Київ, Україна

ДРАЧ Ірина Іванівна

доктор педагогічних наук, доцент,

в.о. директора Інституту вищої освіти НАПН України, м. Київ, Україна

\section{ДЕБИЧ Марія Андріївна}

доктор педагогічних наук, дочент, головний науковий співробітник відділу забезпечення якості вищої освіти Інституту вищої освіти НАПН України, м. Київ, Україна

ПАЛАМАРЧУК Ольга Федорівна

кандидат педагогічних наук, старший науковий співробітник відділу забезпечення якості вищої освіти Інституту вищої освіти НАПН України, м. Київ, Україна

ТРИМА Катерина Андріївна кандидат політичних наук, старший науковий співробітник відділу взаємодії університетів та суспільства Інституту вищої освіти НАПН України, м. Київ, Україна 
Анотація. Стаття присвячена проблемі визначення початку і завершення навчального року у закладах загальної середньої та вищої освіти зарубіжних країн. Наведено ключові особливості встановлення термінів навчання, що зумовлено географічним розташуванням країн (у північній чи південній півкулі), урахуванням історичного досвіду і національних традицій. Обгрунтовано, що кожен заклад вищої освіти автономний у вирішенні багатьох питань своєї діяльності, зокрема щодо організації, початку і завершення навчального року. На підставі здійсненого аналізу спеціальних досліджень і нових політик останнього десятиріччя іноземних країн, міжнародних організацій і міжнародних органів щодо змін часових та організаційних параметрів навчального прочесу у закладах загальної середньої освіти у зв'язку зі змінами клімату, наведено провідні тенденції та перелік основних документів міжнародних організацій щодо проблеми зміни клімату.

Ключові слова: початок навчального року; завершення навчального року; шкільні канікули; освітній прочес; кліматичні зміни; терміни навчання.

Порівняльні дати початку навчального року і завершення навчального року у закладах загальної середньої освіти зарубіжних країн першої фокус-групи ${ }^{1}$

Дати початку та закінчення навчального року в країнах світу офіційно визначаються профільним міністерством країни для кожного навчального року. У країнах з децентралізованою освітою міністерства встановлюють орієнтовні дати, які адаптуються на рівні штатів/регіонів/провінцій/ земель до місцевих умов місцевою (штату/ регіону/провінції/землі) владою в рамках національно визначених дат.

Початок і закінчення навчального року в школах країн світу значною мірою залежить від розташування країни - у північній чи південній півкулі. У країнах Європи, Північної Америки, Азії (наприклад, Іран) навчальний рік зазвичай розпочинається упродовж серпня-вересняжовтня і закінчується наступного року наприкінці травня, у червні, на початку липня (табл. 1). У країнах південної півкулі (Австралії, Новій Зеландії) навчальний рік структуровано в рамках календарного року та розпочинається 3 кінця січня - на початку лютого, закінчується у грудні. Наприклад, у Новій Зеландії в 2021 р. шкільний рік розпочався між 1 лютого та 9 лютого залежно від регіону, у 2022 р. - розпочнеться між 31 січня та 8 лютого. Водночас у Нігерії, яка розташована у північній півкулі, навчальний рік розпочинається у січні і закінчується у грудні.

У країнах Східної Азії (Японії, Південній Кореї) навчальний рік розпочинається весною і закінчується через 11 місяців наступного року: у Південній Кореї навчальний рік зазвичай триває 3 березня по лютий, у Японії - розпочинається у квітні і закінчується наступного березня, перерви влітку, взимку та весною розділяють на три терміни.

\footnotetext{
${ }^{1}$ Інформацію подано за результатами аналізу інформаційної мережі Eurydice (країни Європи) та профільних міністерств для країн світу.
}

Найраніше в країнах Європи навчальний рік розпочинається в Данії (10-12 серпня). У багатьох країнах Європи навчальний рік у школі розпочинається на початку вересня. У Бельгії, Чехії, Литві, Польщі, Угорщині та деяких інших країнах діти йдуть до школи 1 вересня. У Німеччині, хоч офіційна дата початку $€ 1$ серпня, на практиці школи в різних землях розпочинають заняття у період $з 3$ серпня по 14 вересня. У країнах/ регіонах Південної Європи (наприклад, Албанії, Греції, Італії, Португалії та Іспанії), а також у Болгарії та Люксембурзі датою початку зазвичай $€$ середина вересня. В Австрії, Німеччині, Іспанії, Італії, Нідерландах та Швейцарії початок та кінець навчального року значно відрізняються залежно від регіонів. У США навчальний рік у школах розпочинається з кінця серпня/початку вересня (залежно від штату) та закінчується наприкінці червня.

Табличя 1

Дати початку і завершення навчального року у закладах загальної середньої освіти країн першої фокус-групи

\begin{tabular}{|c|c|c|}
\hline Країна & $\begin{array}{c}\text { Дата початку } \\
\text { навчального року }\end{array}$ & $\begin{array}{l}\text { Дата завершення } \\
\text { навчального року }\end{array}$ \\
\hline Австралія & $\begin{array}{l}\text { кінець січня - } \\
\text { початок лютого }\end{array}$ & середина грудня \\
\hline Австрія & 7 вересня & 2 липня \\
\hline Азербайджан & 15 вересня & 15 червня \\
\hline Албанія & 14 вересня & $\begin{array}{l}8 \text { червня } \\
\text { (середня школа) } \\
15 \text { червня } \\
\text { (старша школа) }\end{array}$ \\
\hline Алжир & $\begin{array}{l}21 \text { жовтня } \\
\text { (початкова школа) } \\
4 \text { листопада } \\
\text { (середня школа) }\end{array}$ & 7 липня \\
\hline Вірменія & 1 вересня & 22 червня \\
\hline Бельгія & 1 вересня & 30 червня \\
\hline Білорусь & 1 вересня & 31 травня \\
\hline Беліз & 2 вересня & 29 червня \\
\hline
\end{tabular}


Таблиия 1 (продовження)

\begin{tabular}{|c|c|c|}
\hline Країна & $\begin{array}{c}\text { Дата початку } \\
\text { навчального року }\end{array}$ & $\begin{array}{l}\text { Дата завершення } \\
\text { навчального року }\end{array}$ \\
\hline Болгарія & 15 вересня & $\begin{array}{l}31 \text { травня } \\
\text { (початкова школа) } \\
14 \text { червня } \\
\text { (середня школа) } \\
30 \text { червня } \\
\text { (старша школа) }\end{array}$ \\
\hline $\begin{array}{l}\text { Боснія і } \\
\text { Герцеговина }\end{array}$ & 1 вересня & 18 червня \\
\hline $\mathrm{B}^{\prime} \in \mathrm{Tнам}$ & 5 вересня & 29 травня \\
\hline Греція & 14 вересня & $\begin{array}{l}15 \text { червня } \\
\text { (початкова школа) } \\
30 \text { червня } \\
\text { (середня школа) }\end{array}$ \\
\hline Грузія & 15 вересня & 15 червня \\
\hline Данія & $\begin{array}{l}10 \text { серпня } \\
\text { (початкова школа) } \\
12 \text { серпня } \\
\text { (середня школа) }\end{array}$ & 26 червня \\
\hline $\begin{array}{l}\text { Домініканська } \\
\text { Республіка }\end{array}$ & середина серпня & $\begin{array}{l}24 \text { травня } \\
\text { (початкова школа) } \\
28 \text { травня } \\
\text { (середня школа) }\end{array}$ \\
\hline Ефіопія & 25 серпня & 17 червня \\
\hline Єгипет & 12 вересня & 21 червня \\
\hline Ізраїль & 1 вересня & $\begin{array}{l}30 \text { червня } \\
\text { (початкова школа) } \\
19 \text { червня } \\
\text { (середня школа) }\end{array}$ \\
\hline Індія & $\begin{array}{l}1 \text { липня } \\
\text { (північні штати) } \\
\text { початок червня } \\
\text { (південні штати) }\end{array}$ & березень \\
\hline Індонезія & 15 липня & 15 червня \\
\hline Іспанія & $\begin{array}{l}\text { 4-17 вересня } \\
\text { (початкова школа) } \\
\text { 9-29 вересня } \\
\text { (середня школа) }\end{array}$ & $\begin{array}{l}\text { 18-25 червня } \\
\text { (початкова школа) } \\
\text { 16-25 червня } \\
\text { (середня школа) }\end{array}$ \\
\hline Італія & 7-24 вересня & 5-16 червня \\
\hline Іран & 21 серпня & 21 липня \\
\hline Йорданія & $\begin{array}{l}26 \text { серпня - } \\
4 \text { вересня }\end{array}$ & 16 червня \\
\hline Казахстан & 1 вересня & 25 травня \\
\hline Канада & $\begin{array}{l}7 \text { вересня (загаль- } \\
\text { нонаціональна } \\
\text { дата): } \\
\text { Альберта - } \\
\text { 1/3 вересня; }\end{array}$ & $\begin{array}{l}25 \text { червня (загаль- } \\
\text { нонаціональна } \\
\text { дата) остання } \\
\text { п'ятниця червня: } \\
\text { Альберта - } \\
\text { 24/28 червня; }\end{array}$ \\
\hline
\end{tabular}

Таблиия 1 (продовження)

\begin{tabular}{|c|c|c|}
\hline Країна & $\begin{array}{c}\text { Дата початку } \\
\text { навчального року }\end{array}$ & $\begin{array}{l}\text { Дата завершення } \\
\text { навчального року }\end{array}$ \\
\hline & $\begin{array}{l}\text { Британська } \\
\text { Колумбія - } \\
\text { 7/8/9 вересня; } \\
\text { Манітоба - } \\
\text { 7/8/9 вересня; } \\
\text { Онтаріо - } \\
2 \text { тиждень } \\
\text { вересня; } \\
\text { Саскачеван - } \\
1 \text { вересня або } \\
\text { перший тиждень } \\
\text { вересня }\end{array}$ & $\begin{array}{l}\text { Британська } \\
\text { Колумбія - } \\
\text { 23/29 червня; } \\
\text { Манітоба - } \\
\text { 29/30 червня; } \\
\text { Онтаріо - } \\
30 \text { червня; } \\
\text { Саскачеван - } \\
\text { 28/29 червня }\end{array}$ \\
\hline Киргизстан & 15 вересня & 8 червня \\
\hline KHP & 1 вересня & $\begin{array}{l}30 \text { червня } \\
\text { (можуть бути } \\
\text { регіональні } \\
\text { варіації) }\end{array}$ \\
\hline Куба & 13 серпня & 25 травня \\
\hline Ліван & 14 серпня & 23 травня \\
\hline Литва & 1 вересня & 1 липня \\
\hline Люксембург & 15 вересня & 15 липня \\
\hline Малайзія & 20 січня & $\begin{array}{l}\text { третій тиждень } \\
\text { листопада }\end{array}$ \\
\hline Мексика & $\begin{array}{l}\text { друга половина } \\
\text { серпня }\end{array}$ & початок липня \\
\hline Молдова & 1 вересня & 31 травня \\
\hline Марокко & 3 вересня & 17 червня \\
\hline Нігерія & $\begin{array}{l}\text { третій тиждень } \\
\text { вересня }\end{array}$ & середина липня \\
\hline Нікарагуа & 4 лютого & 28 листопада \\
\hline Німеччина & $\begin{array}{l}\text { початок вересня, } \\
\text { проте в кожній } \\
\text { федеральній } \\
\text { землі діють свої } \\
\text { закони, тому } \\
\text { дати можуть } \\
\text { змінюватися }\end{array}$ & $\begin{array}{l}31 \text { липня, } \\
\text { проте у кожній } \\
\text { федеральній } \\
\text { землі діють свої } \\
\text { закони, тому } \\
\text { дати можуть } \\
\text { змінюватися }\end{array}$ \\
\hline Нідерланди & $\begin{array}{l}\text { Північний регіон: } \\
17 \text { серпня, } \\
\text { Центральний } \\
\text { регіон: } 31 \text { серпня, } \\
\text { Південний регіон: } \\
24 \text { серпня }\end{array}$ & $\begin{array}{l}\text { Північний регіон: } \\
10 \text { липня, } \\
\text { Центральний } \\
\text { регіон: } 17 \text { липня, } \\
\text { Південний регіон: } \\
24 \text { липня }\end{array}$ \\
\hline Нова Зеландія & $\begin{array}{l}\text { між } 1 \text { лютого та } \\
9 \text { лютого залежно } \\
\text { від регіону у } \\
2021 \text { р.; у } 2022 \text { р. } \\
\text { навчальний рік } \\
\text { розпочнеться } \\
\text { між } 31 \text { січня та } \\
8 \text { лютого }\end{array}$ & 20 грудня \\
\hline
\end{tabular}


Таблиия 1 (продовження)

\begin{tabular}{|c|c|c|}
\hline Країна & $\begin{array}{c}\text { Дата початку } \\
\text { навчального року }\end{array}$ & $\begin{array}{l}\text { Дата завершення } \\
\text { навчального року }\end{array}$ \\
\hline $\begin{array}{l}\text { Північна } \\
\text { Македонія }\end{array}$ & 1 жовтня & 10 червня \\
\hline OAE & $\begin{array}{l}29 \text { серпня } 2021 \text { р., } \\
28 \text { серпня } \\
2022 \text { р. - ці дати є } \\
\text { єдиними для всіх } \\
\text { Еміратів }\end{array}$ & $\begin{array}{l}\text { середина - } \\
\text { кінець червня } \\
\text { (тривалість } \\
\text { літніх канікул } \\
\text { не повинна } \\
\text { перевищувати } \\
\text { 8,2 тижні) } \\
\text { Дубай - } 5 \text { липня }\end{array}$ \\
\hline Пакистан & серпень & травень \\
\hline Панама & $\begin{array}{l}\text { кінець лютого - } \\
\text { початок березня } \\
1 \text { березня } 2021 \text { р. }\end{array}$ & $\begin{array}{l}\text { середина грудня } \\
17 \text { грудня } 2021 \text { р. }\end{array}$ \\
\hline $\begin{array}{l}\text { Південна } \\
\text { Корея }\end{array}$ & березень & $\begin{array}{l}\text { лютий наступного } \\
\text { року }\end{array}$ \\
\hline Португалія & 14-17 вересня & 30 червня \\
\hline Румунія & 14 вересня & 18 червня \\
\hline $\begin{array}{l}\text { Саудівська } \\
\text { Аравія }\end{array}$ & 17 серпня & 15 травня \\
\hline Сенегал & середина серпня & 9 липня \\
\hline Сінгапур & 4 січня 2021 p. & 19 листопада \\
\hline Словаччина & 2 вересня & 30 червня \\
\hline Словенія & 1 вересня & $\begin{array}{l}\text { для єдиної } \\
\text { структури школи: } \\
24 \text { червня та } \\
15 \text { червня } \\
\text { (випускний клас); } \\
\text { для старшої школи: } \\
24 \text { червня та } \\
21 \text { червня } \\
\text { (випускний клас) }\end{array}$ \\
\hline США & $\begin{array}{l}\text { Гаваї - } 3 \text { серпня } \\
\text { Джорджія - } \\
\text { 1-2 тиждень серпня } \\
\text { Каліфорнія - } \\
\text { 2-3-4 тиждень } \\
\text { серпня } \\
\text { Нью-Йорк - } \\
4 \text { тиждень серпня, } \\
\text { 1-2 тиждень вересня } \\
\text { Південна } \\
\text { Кароліна - } \\
\text { 3-4 тиждень серпня } \\
\text { луїзіана - } \\
\text { 3-4 тиждень серпня } \\
\text { Техас - } \\
\text { 3-4 тиждень } \\
\text { серпня } \\
\text { Флорида - } \\
\text { 2-3 тиждень серпня }\end{array}$ & $\begin{array}{l}\text { Гаваї - } 26 \text { травня } \\
\text { Джорджія - } \\
4 \text { тиждень травня } \\
\text { Каліфорнія - } \\
\text { 1-2-3 тиждень } \\
\text { червня } \\
\text { Нью-Йорк - } \\
\text { 3-4 тиждень червня } \\
\text { Південна } \\
\text { Кароліна - } \\
\text { 1-2-3 тиждень } \\
\text { червня } \\
\text { Луїзіана - } \\
\text { 3-4 тиждень травня } \\
\text { Техас- } \\
\text { 3-4 тиждень травня, } \\
\text { 1 тиждень червня } \\
\text { Флорида - } \\
\text { 3-4 тиждень травня }\end{array}$ \\
\hline
\end{tabular}

Таблиия 1 (продовження)

\begin{tabular}{|c|c|c|}
\hline Країна & $\begin{array}{c}\text { Дата початку } \\
\text { навчального року }\end{array}$ & $\begin{array}{l}\text { Дата завершення } \\
\text { навчального року }\end{array}$ \\
\hline & $\begin{array}{l}\text { Невада - } \\
\text { 2-3-4 тиждень } \\
\text { серпня } \\
\text { Нью-Мексико - } \\
\text { 2-3 тиждень } \\
\text { серпня } \\
\text { Нью-Джерсі - } \\
\text { 1-2 тиждень } \\
\text { вересня }\end{array}$ & $\begin{array}{l}\text { Невада - } \\
\text { 1-2 тиждень } \\
\text { червня } \\
\text { Нью-Мексико - } \\
\text { останній тиждень } \\
\text { травня } \\
\text { Нью-Джерсі - } \\
\text { 2-3 тиждень } \\
\text { червня }\end{array}$ \\
\hline Таджикистан & 1 вересня & 14 червня \\
\hline Таїланд & 27 серпня & 26 липня \\
\hline Туреччина & $\begin{array}{l}31 \text { серпня } 2020 \text { р. } \\
\text { (онлайн через } \\
\text { COVID-19) } \\
21 \text { вересня } 2020 \text { p. } \\
\text { (очно) } \\
\text { у } 2021 \text { р. - } \\
6 \text { вересня }\end{array}$ & 18 червня \\
\hline Туркменістан & 1 вересня & кінець червня \\
\hline Угорщина & 1 вересня & 15 червня \\
\hline Узбекистан & 1 вересня & кінець червня \\
\hline Філіппіни & 13 вересня 2021 р. & 24 червня 2022 р. \\
\hline Франція & 1 вересня & 6 липня \\
\hline Хорватія & 7 вересня & $\begin{array}{l}18 \text { червня } \\
25 \text { травня } 2021 \text { р. } \\
\text { в останньому році } \\
\text { старшої школи }\end{array}$ \\
\hline Чехія & 1 вересня & 3 червня \\
\hline Чорногорія & 1 жовтня & 18 червня \\
\hline Швейцарія & 10-30 серпня & $\begin{array}{l}18 \text { червня - } \\
16 \text { липня }\end{array}$ \\
\hline Японія & квітень & $\begin{array}{l}\text { березень } \\
\text { наступного року }\end{array}$ \\
\hline
\end{tabular}

Порівняльні дати початку навчального року і завершення навчального року у закладах вищої освіти ${ }^{2}$ країн першої фокус-групи (табл. 2)

таблиця $2^{3}$

Дати початку і завершення навчального року у закладах вищої освіти країн першої фокус-групи

\begin{tabular}{|c|l|l|}
\hline Країна & $\begin{array}{c}\text { Дата початку } \\
\text { навчального року }\end{array}$ & $\begin{array}{c}\text { Дата завершення } \\
\text { навчального року }\end{array}$ \\
\hline Фінляндія & 1 серпня & 31 липня \\
\hline
\end{tabular}

2 Інформацію подано за результатами аналізу інформаційної мережі Eurydice (країни Європи) та профільних міністерств для країн світу.

3 у Таблиці відображено актуальні на 2020-2021 рр. дати початку занять. На сайтах міністерств освіти наявна інформація, що через обмеження, пов'язані з пандемією, можливі зміни щодо початку/завершення навчального року. 
Таблиия 2 (продовження)

\begin{tabular}{|c|c|c|}
\hline Країна & $\begin{array}{c}\text { Дата початку } \\
\text { навчального року }\end{array}$ & $\begin{array}{l}\text { Дата завершення } \\
\text { навчального року }\end{array}$ \\
\hline Румунія & $\begin{array}{l}1 \text { робочий день } \\
\text { жовтня }\end{array}$ & 30 вересня \\
\hline Сенегал & жовтень & липень \\
\hline Сінгапур & січень & листопад \\
\hline Словаччина & 1 вересня & 31 серпня \\
\hline Словенія & 1 жовтня & 30 вересня \\
\hline США & $\begin{array}{l}\text { ЗВО визначають } \\
\text { самостійно } \\
\text { серпень - } \\
\text { вересень }\end{array}$ & $\begin{array}{l}\text { ЗВО визначають } \\
\text { самостійно } \\
\text { травень - } \\
\text { червень }\end{array}$ \\
\hline Таджикистан & 1 вересня & 30 червня \\
\hline Таїланд & серпень & травень \\
\hline Туреччина & $\begin{array}{l}\text { вересень - } \\
\text { жовтень } \\
\text { (ЗВО визначають } \\
\text { самостійно) }\end{array}$ & $\begin{array}{l}\text { червень - } \\
\text { початок липня } \\
\text { (ЗВО визначають } \\
\text { самостійно) }\end{array}$ \\
\hline Туркменістан & 1 вересня & 30 червня \\
\hline Угорщина & $\begin{array}{l}\text { 1-10 вересня } \\
\text { (3ВО визначають } \\
\text { самостійно) }\end{array}$ & $\begin{array}{l}\text { друга половина } \\
\text { червня } \\
\text { (ЗВО визначають } \\
\text { самостійно) }\end{array}$ \\
\hline Узбекистан & $\begin{array}{l}1 \text { вересня } \\
\text { (у } 2021 \text { р. - } \\
6 \text { вересня) }\end{array}$ & 30 червня \\
\hline Філіппіни & $\begin{array}{l}\text { перший понеділок } \\
\text { червня } \\
\text { (ЗВО визначають } \\
\text { самостійно) }\end{array}$ & $\begin{array}{l}\text { березень } \\
\text { (ЗВО визначають } \\
\text { самостійно) }\end{array}$ \\
\hline Франція & $\begin{array}{l}1 \text { вересня - } \\
15 \text { жовтня }\end{array}$ & $\begin{array}{l}\text { червень - } \\
\text { початок липня }\end{array}$ \\
\hline Хорватія & 1 жовтня & 30 вересня \\
\hline Чорногорія & 28 вересня & 18 липня \\
\hline
\end{tabular}

Таблиия 2 (продовження)

\begin{tabular}{|l|l|l|}
\hline \multicolumn{1}{|c|}{ країна } & \multicolumn{1}{|c|}{$\begin{array}{l}\text { Дата початку } \\
\text { навчального року }\end{array}$} & $\begin{array}{l}\text { Дата завершення } \\
\text { навчального року }\end{array}$ \\
\hline Чехія & $\begin{array}{l}\text { вересень/початок } \\
\text { жовтня (3ВО } \\
\text { визначають } \\
\text { самостійно) }\end{array}$ & $\begin{array}{l}\text { 3ВО визначають } \\
\text { самостійно, } \\
\text { навчальний рік } \\
\text { завершується за } \\
\text { добу напередодні } \\
\text { початку нового } \\
\text { навчального року }\end{array}$ \\
\hline Швейцарія & 1 серпня & 31 липня \\
\hline Японія & $\begin{array}{l}1 \text { квітня/початок } \\
\text { квітня }\end{array}$ & 31 березня \\
\hline Австралія & $\begin{array}{l}\text { чотири семестри } \\
27 \text { січня } \\
19 \text { квітня } \\
12 \text { липня }\end{array}$ & $\begin{array}{l}\text { чотири семестри } \\
1 \text { квітня } \\
25 \text { червня } \\
17 \text { вересня } \\
10 \text { грудня }\end{array}$ \\
& жовтня &
\end{tabular}

Порівняльні дати початку і завершення навчального року у закладах загальної середньої освіти країн першої фокус-групи: Сполученого Королівства Великої Британії та Північної Ірландії, Естонії, Ірландії, Латвії, Швеції, Норвегії, РФ, Фінляндії

Найраніше з аналізованих країн новий навчальний рік розпочинають скандинавські країни початок припадає на середину (Фінляндія), другу половину (Норвегія) та кінець (Швеція) серпня. Естонія, Латвія, РФ традиційно розпочинають новий навчальний рік 1 вересня. У Сполученому Королівстві Великої Британії та Північної Ірландії 2020/2021 навчальний рік розпочався 2 вересня 2020 р. та закінчився 23 липня 2021 р. В Ірландії традиційно навчальний рік розпочинається 3 тижня, на який припадає 1 вересня. Закінчення навчального року може варіюватися для початкових та середніх шкіл (наприклад, Ірландія) або бути єдиним (Норвегія, Фінляндія) (табл. 3).

Дати початку і завершення навчального року у закладах загальної середньої освіти Сполученого Королівства Великої Британії та Північної Ірландії, Естонії, Ірландії, Латвії, Швеції, Норвегії, РФ, Фінляндії

\begin{tabular}{|c|c|c|}
\hline Порівняльні дані & Початкова та базова середня освіта & Загальна старша середня освіта \\
\hline \multicolumn{3}{|c|}{ Сполучене Королівство Великої Британії та Північної Ірландії } \\
\hline Дата початку навчального року & перший тиждень вересня 2020 р. & перший тиждень вересня 2020 р. \\
\hline Закінчення навчального року & середина - кінець липня 2021 р. & середина - кінець липня 2021 р. \\
\hline Структура навчального року & три семестри & три семестри \\
\hline \multicolumn{3}{|c|}{ Канікули } \\
\hline \multicolumn{3}{|c|}{ Англія } \\
\hline Осінні & 26 жовтня - 30 жовтня 2020 р. & 26 жовтня - 30 жовтня 2020 р. \\
\hline Різдвяні & 21 грудня - 1 січня 2021 р. & 21 грудня - 1 січня 2021 р. \\
\hline
\end{tabular}


Табличя 3 (продовження)

\begin{tabular}{|c|c|c|}
\hline Порівняльні дані & Початкова та базова середня освіта & Загальна старша середня освіта \\
\hline Лютневі & 15 лютого - 19 лютого 2021 р. & 15 лютого - 19 лютого 2021 р. \\
\hline Великодні & 2 квітня - 16 квітня 2021 р. & 2 квітня - 16 квітня 2021 р. \\
\hline Травневі & 31 травня - 4 червня 2021 р. & 31 травня - 4 червня 2021 р. \\
\hline Літні & 23 липня - 1 вересня 2021 р. & 23 липня - 1 вересня 2021 р. \\
\hline \multicolumn{3}{|c|}{ Уельс } \\
\hline Осінні & 26 жовтня - 1 листопада 2020 р. & 26 жовтня - 1листопада 2020 р. \\
\hline Різдвяні & 19 грудня - 3 січня 2021 р. & 19 грудня - 3 січня 2021 р. \\
\hline Лютневі & 1 тиждень між 15-28 лютого 2021 р. & 1 тиждень між 15-28 лютого 2021 р. \\
\hline Великодні & 29 березня - 11 квітня 2021 р. & 29 березня - 11 квітня 2021 р. \\
\hline Травневі & 31 травня - 6 червня 2021 р. & 31 травня - 6 червня 2021 р. \\
\hline Літні & 20 липня - 31 серпня 2021 р. & 20 липня - 31 серпня 2021 р. \\
\hline \multicolumn{3}{|c|}{ Шотландія } \\
\hline Осінні & $\begin{array}{l}\text { 1-2 тижні у період між 5-27 жовтня } \\
2020 \text { р. }\end{array}$ & 1-2 тижні між 5-27 жовтня 2020 р. \\
\hline Різдвяні & $\begin{array}{l}2 \text { тижні між } 21 \text { грудня } 2020 \text { р. - } \\
6 \text { січня } 2021 \text { р. }\end{array}$ & $\begin{array}{l}2 \text { тижні між } 21 \text { грудня } 2020 \text { р. - } \\
6 \text { січня } 2021 \text { р. }\end{array}$ \\
\hline Лютневі & $\begin{array}{l}1 \text { день - } 1 \text { тиждень між 5-22 лютого } \\
2021 \text { р. }\end{array}$ & $\begin{array}{l}1 \text { день - } 1 \text { тиждень між 5-22 лютого } \\
2021 \text { р. }\end{array}$ \\
\hline Великодні & $\begin{array}{l}2 \text { тижні між } 29 \text { березня - } 19 \text { квітня } \\
2021 \text { р. }\end{array}$ & $\begin{array}{l}2 \text { тижні між } 29 \text { березня - } 19 \text { квітня } \\
2021 \text { р. }\end{array}$ \\
\hline Травневі & $\begin{array}{l}\text { до 1-го тижня у період між } 3 \text { квітня - } \\
14 \text { травня } 2021 \text { р. }\end{array}$ & $\begin{array}{l}\text { до 1-го тижня } 3 \text { квітня - } 14 \text { травня } \\
2021 \text { р. }\end{array}$ \\
\hline Літні & $\begin{array}{l}6 \text { тижнів між } 28 \text { червня - } 18 \text { серпня } \\
2021 \text { р. }\end{array}$ & $\begin{array}{l}6 \text { тижнів між } 28 \text { червня }-18 \text { серпня } \\
2021 \text { р. }\end{array}$ \\
\hline \multicolumn{3}{|c|}{ Північна Ірландія } \\
\hline Осінні & 26 жовтня - 1 листопада 2020 р. & 26 жовтня - 1 листопада 2020 р. \\
\hline Різдвяні & 22 грудня 2020 р. - 2 січня 2021 р. & 22 грудня 2020 р. - 2 січня 2021 р. \\
\hline Великодні & 1-9 квітня 2021 р. & 1-9 квітня 2021 р. \\
\hline Літні & 1 липня - 28 серпня 2021 р. & 1 липня - 28 серпня 2021 р. \\
\hline \multicolumn{3}{|c|}{ Естонія } \\
\hline Дата початку навчального року & 1 вересня 2020 р. & 1 вересня 2020 р. \\
\hline Закінчення навчального року & 31 серпня 2021 р. & 31 серпня 2021 р. \\
\hline Структура навчального року & 4 чверті (35 тижнів) & 4 чверті (37 тижнів) \\
\hline \multicolumn{3}{|c|}{ Канікули } \\
\hline Осінь & 19-25 жовтня 2020 р. & 19-25 жовтня 2020 р. \\
\hline Різдво/Новий рік & 23 грудня 2020 р. - 10 січня 2021 р. & 23 грудня 2020 р. - 10 січня 2021 р. \\
\hline Другі зимові канікули & 22-28 лютого 2021 р. & 22-28 лютого 2021 р. \\
\hline Весна & 19-25 квітня 2021 р. & 19-25 квітня 2021 р. \\
\hline Літо & $\begin{array}{l}14 \text { червня - } 31 \text { серпня } 2021 \text { р. } \\
\text { (12 тижнів) }\end{array}$ & $\begin{array}{l}14 \text { червня - } 31 \text { серпня } 2021 \text { р. } \\
\text { (за винятком випускних класів) }\end{array}$ \\
\hline \multicolumn{3}{|c|}{ Ірландія } \\
\hline Дата початку навчального року & перший тиждень вересня 2020 р. & приблизно 24 серпня 2020 р. \\
\hline
\end{tabular}


Табличя 3 (продовження)

\begin{tabular}{|c|c|c|}
\hline Порівняльні дані & Початкова та базова середня освіта & Загальна старша середня освіта \\
\hline Закінчення навчального року & кінець червня 2021 р. & $\begin{array}{l}\text { завершення державних іспитів у } \\
\text { червні } 2021 \text { р. }\end{array}$ \\
\hline Структура навчального року & три семестри & три семестри \\
\hline \multicolumn{3}{|c|}{ Канікули } \\
\hline Осінь & 26-30 жовтня 2020 р. & 26-30 жовтня 2020 р. \\
\hline Різдво/Новий рік & 23 грудня 2020 р. - 5 січня 2021 р. & 23 грудня 2020 р. - 5 січня 2021 р. \\
\hline Зима/Карнавал & 18-19 лютого 2021 р. & 15-19 лютого 2021 р. \\
\hline Весна/Великдень & 29 березня - 9 квітня 2021 р. & 19-25 квітня 2021 р. \\
\hline Літо & $\begin{array}{l}\text { наприкінці червня до } 1 \text { вересня } \\
2021 \text { р. (приблизно } 9 \text { тижнів) }\end{array}$ & $\begin{array}{l}\text { червень, липень та більшість серпня } \\
2021 \text { р. (приблизно } 12 \text { тижнів) }\end{array}$ \\
\hline \multicolumn{3}{|c|}{ Латвія } \\
\hline Дата початку навчального року & 1 вересня 2020 р. & 1 вересня 2020 р. \\
\hline Закінчення навчального року & 31 травня 2021 р. & 31 травня 2021 р. \\
\hline Структура навчального року & два семестри & два семестри \\
\hline \multicolumn{3}{|c|}{ Канікули } \\
\hline Осінь & 19-23 жовтня 2020 р. & 19-23 жовтня 2020 р. \\
\hline Різдво/Новий рік & 21 грудня 2020 р. - 1 січня 2021 р. & 21 грудня 2020 р. - 1 січня 2021 р. \\
\hline Весна/Великдень & 15-19 березня 2021 р. & $\begin{array}{l}\text { 15-19 березня } 2021 \text { р. } \\
\text { 22-26 березня } 2021 \text { р. (для } 12 \text { класу) }\end{array}$ \\
\hline Літо & $\begin{array}{l}1 \text { червня - } 31 \text { серпня } 2021 \text { р. } \\
\text { (13 тижнів) }\end{array}$ & $\begin{array}{l}1 \text { червня - } 31 \text { серпня } 2021 \text { р. } \\
\text { (13 тижнів) }\end{array}$ \\
\hline \multicolumn{3}{|c|}{ Швеція } \\
\hline Дата початку навчального року & кінець серпня 2020 р. & кінець серпня 2020 р. \\
\hline Закінчення навчального року & середина червня 2021 р. & середина червня 2021 р. \\
\hline Структура навчального року & два семестри & два семестри \\
\hline \multicolumn{3}{|c|}{$\begin{array}{l}\text { Відповідно до шкільного розпорядження та постанови про старшу середню школу, навчальний рік складається щонайменше } \\
\text { з } 178 \text { навчальних днів та щонайменше з } 12 \text { днів канікул - точні дати варіюються на регіональному та муніципальному } \\
\text { рівнях. Окрім шкільних днів та канікул, школи можуть проводити для персоналу (максимум) п'ять днів підвищення } \\
\text { кваліфікації. }\end{array}$} \\
\hline \multicolumn{3}{|c|}{ Канікули } \\
\hline Осінь & 26-30 жовтня 2020 р. & 26-30 жовтня 2020 р. \\
\hline Різдво/Новий рік & $\begin{array}{l}\text { початок - 18-22 грудня } 2020 \text { р. } \\
\text { кінець - 7-12 січня } 2021 \text { р. }\end{array}$ & $\begin{array}{l}\text { початок - 18-22 грудня } 2020 \text { р. } \\
\text { кінець - 7-12 січня } 2021 \text { р. }\end{array}$ \\
\hline Другі зимові канікули & 15 лютого - 13 березня 2021 р. & 15 лютого - 13 березня 2021 р. \\
\hline Весна/Великдень & між 29 березня - 16 квітня 2021 р. & між 29 березня - 16 квітня 2021 р. \\
\hline Літо & приблизно 10 тижнів & приблизно 10 тижнів \\
\hline \multicolumn{3}{|c|}{ Норвегія } \\
\hline Дата початку навчального року & між 17 та 24 серпня 2020 р. & між 17 та 24 серпня 2020 р. \\
\hline Закінчення навчального року & 18 червня 2021 р. & 18 червня 2021 р. \\
\hline Структура навчального року & два семестри & два семестри \\
\hline \multicolumn{3}{|c|}{ Канікули } \\
\hline Осінь & $\begin{array}{l}1 \text { тиждень (іноді лише 2-3 дні) між } \\
28 \text { вересня - } 16 \text { жовтня } 2020 \text { р. }\end{array}$ & $\begin{array}{l}1 \text { тиждень (іноді лише 2-3 дні) між } \\
28 \text { вересня - } 16 \text { жовтня } 2020 \text { р. }\end{array}$ \\
\hline
\end{tabular}


Табличя 3 (продовження)

\begin{tabular}{|c|c|c|}
\hline Порівняльні дані & Початкова та базова середня освіта & Загальна старша середня освіта \\
\hline Різдво/Новий рік & $\begin{array}{l}\text { між } 21 \text { грудня } 2020 \text { р. та } 1 \text { тижнем } \\
\text { січня } 2021 \text { р. }\end{array}$ & $\begin{array}{l}\text { між } 21 \text { грудня } 2020 \text { р. та } 1 \text { тижнем } \\
\text { січня } 2021 \text { р. }\end{array}$ \\
\hline Другі зимові канікули & 15 лютого - 5 березня 2021 р. & 15 лютого - 5 березня 2021 р. \\
\hline Весна/Великдень & 29 березня - 6 квітня 2021 р. & 29 березня - 6 квітня 2021 р. \\
\hline Літо & 21 червня - 20 серпня 2021 р. & 21 червня - 20 серпня 2021 р. \\
\hline \multicolumn{3}{|c|}{ Російська Федерація } \\
\hline Дата початку навчального року & 1 вересня & 1 вересня \\
\hline Закінчення навчального року & 21 травня (34 тижні) & 25 травня, 31 травня (37 тижнів)* \\
\hline Структура навчального року & $\begin{array}{l}\text { чотири чверті або триместри } \\
\text { (модульна система) }\end{array}$ & $\begin{array}{l}\text { чотири чверті або триместри } \\
\text { (модульна система) }\end{array}$ \\
\hline \multicolumn{3}{|c|}{ * випускники 9-х та 11-х класів, у яких у червні заплановані ОГЕ і ЄДІ навчатимуться більше. } \\
\hline \multicolumn{3}{|c|}{ Канікули } \\
\hline Осінь & 19-25 жовтня 2020 р.* & 19-25 жовтня 2020 р.* \\
\hline Різдво/Новий рік & 28 грудня 2020 р. - 10 січня 2021 р. & 28 грудня 2020 р. - 10 січня 2021 р. \\
\hline Весна/Великдень & 22-28 березня 2021 р.* & 22-28 березня 2021 р.* \\
\hline Літо & 31 травня - 31 серпня 2021 р. & 31 травня - 31 серпня 2021 р. \\
\hline \multicolumn{3}{|c|}{ * дати канікул можуть зрушуватися на 1 тиждень вперед або назад. } \\
\hline \multicolumn{3}{|c|}{$\begin{array}{l}\text { Календар шкільних канікул для триместрової структури навчання: перші осінні }-5 \text {-11 жовтня } 2020 \text { р.; другі } \\
\text { осінні - 16-22 листопада } 2020 \text { р.; новорічні - } 28 \text { грудня } 2020 \text { р. }-10 \text { січня } 2021 \text { р.; лютневі канікули - } \\
\text { 15-21 лютого } 2021 \text { р.; весняні - 5-11 квітня } 2021 \text { р.; літні }-26 \text { травня }-31 \text { серпня } 2021 \text { р. }\end{array}$} \\
\hline \multicolumn{3}{|c|}{ Фінляндія } \\
\hline Дата початку навчального року & 11-18 серпня 2020 р. & 11-18 серпня 2020 р. \\
\hline Закінчення навчального року & 29-31 травня 2020 р. & 29-31 травня 2020 р. \\
\hline Структура навчального року & два півріччя & два півріччя \\
\hline \multicolumn{3}{|c|}{ Канікули } \\
\hline Осінь & 2-5 днів у жовтні 2020 р. & 2-5 днів у жовтні 2020 р. \\
\hline Різдво/Новий рік & 18-22 грудня 2020 р. & 18-22 грудня 2020 р. \\
\hline Другі зимові канікули & $\begin{array}{l}\text { між } 11 \text { лютого та } 14 \text { березня } 2021 \text { р. } \\
\text { (1 тиждень) }\end{array}$ & $\begin{array}{l}\text { між } 11 \text { лютого та } 14 \text { березня } 2021 \text { р. } \\
\text { (1 тиждень) }\end{array}$ \\
\hline Весна/Великдень & 2-5 квітня 2021 р. & 2-5 квітня 2021 р. \\
\hline Літо & $\begin{array}{l}\text { між } 29 \text { травня до середини серпня } \\
2021 \text { р. (10-11 тижнів) }\end{array}$ & $\begin{array}{l}\text { між } 29 \text { травня до середини серпня } \\
2021 \text { р. (10-11 тижнів) }\end{array}$ \\
\hline
\end{tabular}

Порівняльне дослідження структури навчального року у закладах загальної середньої освіти країн першої фокус-групи

Структура навчального року в країнах світу першої фокус групи охоплює від двох до трьох семестрів, або може тривати чотири чверті залежно від країни. Навіть всередині країни (наприклад, КНР) структура навчального року різниться.

у Європі освітній процес у закладах загальної середньої освіти організовується в межах навча- льного року, який найчастіше структурується на 2-3 семестри.

Навчальний рік у європейських країнах триває в діапазоні 170-190 навчальних днів. Кількість навчальних днів коливається в межах 165 днів у початковій освіті в Албанії, на Мальті та Румунії та 200 днів у Данії та Італії. У частині країн/регіонів навчальний рік триває в діапазоні 181-190 днів. Порівняння засвідчує, що у багатьох європейських країнах кількість навчальних днів є однаковою у початковій та середній освіті. Винятком $€$ 
Албанія, Франція, Румунія та Сербія (у яких навчальних днів більше у старшій школі), і, наприклад, Кіпр та Боснія і Герцеговина, де навчальних днів більше у початковій школі.

Розподіл та тривалість шкільних канікул упродовж навчального року варіюється, за винятком різдвяних канікул. Окрім літніх канікул, у Європі є ще чотири основні періоди шкільних канікул: осінні канікули, Різдво та Новий рік, зимові/карнавальні свята, а також весна/ Великодні свята. За винятком Різдва/Нового року, інші шкільні перерви відрізняються тривалістю і термінами. Оскільки деякі з цих свят пов'язані 3 гнучкими календарними датами (Карнавал та Великдень), їх час з року в рік дещо змінюється. Так само, як і ці загальні свята, країни пропонують додаткові дні відпустки для громадських чи релігійних випадків.

У 19 країнах/регіонах восени школярі зазвичай мають один тиждень канікул; в інших країнах (наприклад, Чехії, Мальті, Словаччині, Сполученому Королівстві Великої Британії та Північної Ірландії, Ісландії) коливається від двох до трьох днів, до трьох тижнів (Швейцарія) або взагалі без свят у 11 країнах (Албанія, Греція, Польща, Чорногорія та Північна Македонія). На Різдво майже всі країни пропонують два тижні свят; в інших країнах: один день у Туреччині та один тиждень у Словенії, і до трьох тижнів у Німеччині. На Карнавал приблизно у 20 країнах/регіонах учні мають один - два тижні на Кіпрі, у Франції, Польщі й Туреччині. Але в деяких країнах у цей період школярі не мають канікул (наприклад, Албанія та Греція).

Весняні/Великодні канікули тривають одиндва тижні у більшості країн Європи, хоча деякі країни (наприклад, Албанія) пропонують лише кілька днів, Швейцарія - до трьох тижнів. У цей період немає канікул у Боснії та Герцеговині та Чорногорії.

Тривалість літніх канікул різна. Навчальний рік зазвичай закінчується з кінця травня до другої половини липня. Середина червня - це час, коли в більшості країн Європи розпочинаються літні канікули. Тривалість літніх канікул різниться: від 6 тижнів у деяких німецьких землях, Нідерландах, Сполученому Королівстві Великої Британії та Північної Ірландії (Англія та Уельс) та Ліхтенштейн, до 13 тижнів у Латвії, від 12 до 14 тижнів у Італії та Португалії (середня освіта), 15 тижнів в Албанії та Болгарії (для початкової школи).

Учні США відвідують школу 180 днів на рік, розпочинаючи з вересня і закінчуючи у червні. Літні канікули тривають з червня до кінця серпня. Навчальний рік ділиться на чотири чверті або два семестри, залежно від школи. Учні зазвичай мають канікули у грудні, лютому та квітні.

Учні Австралії відвідують школу 200 днів на рік. Навчальний рік триває 3 кінця січня до середини грудня. Літні канікули для австралійських учнів тривають із середини грудня до кінця січня. Навчальний рік розподілено на чотири чверті тривалістю від 9 до 11 тижнів.

Більшість японських шкіл працюють за триместровим графіком, а у Південній Кореї рік ділиться на два семестри.

У Нігерії навчальний рік ділиться на три семестри $з$ місячною перервою між кожним семестром.

Порівняльні дати початку і завершення навчального року у закладах вищої освіти країн першої фокус-групи (табл. 4)

Табличя 4

Порівняльні дати початку і завершення навчального року у закладах вищої освіти країн першої фокус-групи

\begin{tabular}{|l|l|l|}
\hline \multicolumn{1}{|c|}{ Країна } & \multicolumn{1}{|c|}{ Дата початку навчального року } & \multicolumn{1}{|c|}{ Дата завершення навчального року } \\
\hline Велика Британія & $\begin{array}{l}\text { ЗВО визначають самостійно, } \\
\text { середина вересня - початок жовтня }\end{array}$ & $\begin{array}{l}\text { 3ВО визначають самостійно, } \\
\text { зазвичай початок/середина червня }\end{array}$ \\
\hline Естонія & $\begin{array}{l}\text { останній тиждень серпня - перший } \\
\text { тиждень вересня }\end{array}$ & $\begin{array}{l}\text { останній тиждень червня - перший тиждень } \\
\text { липня }\end{array}$ \\
\hline Ірландія & друга половина вересня & $\begin{array}{l}\text { навчальний рік завершується у день, коли } \\
\text { починається наступний }\end{array}$ \\
\hline Латвія & перший тиждень вересня & день останнього іспиту весняної чи літньої сесії \\
\hline Швеція & $\begin{array}{l}\text { зВО визначають самостійно, } \\
\text { найчастіше кінець серпня - початок } \\
\text { вересня }\end{array}$ & $\begin{array}{l}\text { кінець травня - початок червня. } \\
\text { Протягом червня-вересня ЗВО пропонують } \\
\text { короткострокові курси }\end{array}$ \\
\hline Норвегія & $\begin{array}{l}\text { зВО визначають самостійно, } \\
\text { найчастіше середина серпня }\end{array}$ & $\begin{array}{l}\text { зВО визначають самостійно, найчастіше } \\
\text { середина червня }\end{array}$ \\
\hline
\end{tabular}

Топузов О.М., Саух П.Ю., Драч І.І., Локшина О.І. та ін., https://doi.org/10.37472/2707-305X-2021-3-2-14-1 
Табличя 4 (продовження)

\begin{tabular}{|c|l|l|}
\hline \multicolumn{1}{|c|}{ Країна } & \multicolumn{1}{|c|}{ Дата початку навчального року } & \multicolumn{1}{|c|}{ Дата завершення навчального року } \\
\hline Російська Федерація & 1 вересня & 30 червня \\
\hline
\end{tabular}

Таким чином, державна влада у переважній більшості країн, зокрема Європейського Союзу, зберігає за собою лише право встановлення узагальнюючих нормативів щодо строків навчання і необхідного мінімуму навчальних годин. Кожен заклад вищої освіти автономний у вирішенні багатьох питань своєї діяльності, у тому числі стосовно організації, початку і завершення навчального року. Однак і в країнах Європейського Союзу структури систем вищої освіти та принципи діяльності в кожній з країн не можна зрозуміти і порівняти, не враховуючи історичний досвід і національні традиції кожної з них. Крім того, потрібно взяти до уваги і тенденцію до все більшої гнучкості освітніх систем, яка виявляється у зростаючому виборі програм, часу, термінів, місця проведення занять, їхній індивідуалізації, більшій орієнтованості на конкретні потреби та інтереси кожного здобувача вищої освіти.

Найбільш характерною особливістю систем вищої освіти країн є відкритість майбутньому, що у поєднанні 3 національним різноманіттям, особливостями, культурою, зумовлюють схожість і відмінність у функціонуванні освітніх систем, дають змогу визначити спільні цілі, нові європейські нормативи, пристосувати формальну і неформальну вищу освіту до потреб суспільства, удосконалити чинні освітні системи та розробити нові стратегії розвитку, незважаючи на їх неоднорідність.

Порівняльне дослідження структури навчального року у закладах вищої освіти у країнах першої фокус-групи

Проаналізовані документи іноземних країн, міжнародних організацій та міжнародних органів щодо впливу клімату/кліматичних змін на організацію навчального року присвячені здебільшого впровадженню екологічної компетентності в освітній процес у ЗВО та поширенню екограмотності серед здобувачів вищої освіти. Недостатнє розгорнуте висвітлення комплексних досліджень із зазначеної проблеми може бути пов'язано з правом університетів на автономію, що дає змогу закладам вищої освіти самостійно приймати рішення щодо адаптації освітнього процесу до кліматичних змін.

Інформація про дослідження і нових політик останнього десятиліття іноземних країн, міжнародних організацій і міжнародних органів щодо змін часових та організаційних параметрів навчального процесу у закладах загальної середньої освіти і в закладах вищої освіти у зв'язку зі змінами клімату

Здійснений аналіз спеціальних досліджень і нових політик останнього десятиріччя іноземних країн, міжнародних організацій і міжнародних органів саме щодо змін часових та організаційних параметрів навчального процесу у закладах загальної середньої освіти у зв'язку зі змінами клімату засвідчує, що:

- зміна клімату є питанням, яким активно опікуються міжнародні організації глобального рівня, передусім ООН, ОЕСР, ЮНЕСКО, ЮНІСЕФ та ін. (перелік проаналізованих документів подано у табл. 5);

- трансляцію учням закладів загальної середньої освіти, професійно-технічної освіти знань щодо зміни клімату міжнародна спільнота позиціонує як пріоритетне завдання. ґрунтовний внесок тут робить ЮНЕСКО, яка розвиває такий напрям як «Освіта про зміну клімату» (перелік проаналізованих документів подано у табл. 6);

- у світі здійснюються дослідження щодо впливу зміни клімату на різні аспекти навчального процесу та результати навчання передусім у регіонах, у яких значно відчуваються такі впливи, зокрема екваторіальний та субекваторіальний пояси (див. табл. 7).

Загалом питання про дослідження і нові політики останнього десятиліття іноземних країн, міжнародних організацій і міжнародних органів щодо змін часових та організаційних параметрів навчального процесу у закладах загальної середньої освіти у зв'язку зі змінами клімату потребує подальшого окремого вивчення.

Таблиия 5

Перелік проаналізованих документів міжнародних організацій щодо проблеми зміни клімату

\begin{tabular}{|l|l|}
\hline \multicolumn{1}{|c|}{ Назва організації } & \multicolumn{1}{|c|}{ Назва документу та коротка анотація } \\
\hline United Nations & $\begin{array}{l}\text { Paмкова конвенція OOH зі зміни клімату / } \\
\text { United Nations Framework Convention on Climate Change (1992) }\end{array}$ \\
\hline
\end{tabular}

Топузов О.М., Саух П.Ю., Драч І.І., Локшина О.І. та ін., https://doi.org/10.37472/2707-305X-2021-3-2-14-1 
Табличя 5 (продовження)

\begin{tabular}{|c|c|}
\hline Назва організації & Назва документу та коротка анотація \\
\hline & $\begin{array}{l}\text { Міжнародний екологічний договір, мета якого полягає в стабілізації концентрації } \\
\text { парникових газів в атмосфері на такому рівні, який не допускав би небезпечного } \\
\text { антропогенного впливу на клімат Землі. }\end{array}$ \\
\hline \multirow[t]{3}{*}{ OECD } & $\begin{array}{l}\text { Strengthening Climate Resilience. Guidance for Governments and Development Co- } \\
\text { operation (2021) } \\
\text { Метою документа є посилення підтримки урядам країн щодо пристосування } \\
\text { людських і природних систем до впливів кліматичних змін. } \\
\text { Кожна країна має виконувати пропонований план дій за рівнями управління в усіх } \\
\text { секторах життя і діяльності. }\end{array}$ \\
\hline & $\begin{array}{l}\text { National Adaptation Planning. Lessons from OECD Countries (2005) } \\
\text { На основі адаптивної стратегії ОЕСР узагальнено стани розробки національних } \\
\text { адаптивних стратегій, підходів (наявність, розробка) на рівнях влади та плановані дії } \\
\text { за прикладами країн-членів. }\end{array}$ \\
\hline & $\begin{array}{l}\text { Policy Forum on Adaptation to Climate Change in OECD Countries (2012) } \\
\text { Представлено розробку адаптивних політик до кліматичних змін серед країн ОЕСР } \\
\text { (загальні виклики, участь приватного сектору, суспільна політика у партнерстві } 3 \\
\text { приватним сектором). }\end{array}$ \\
\hline UNICEF & $\begin{array}{l}\text { An Environment Fit for Children UNICEF's Approach to Climate Change (2019) } \\
\text { Environment and climate change. Climate change and environmental degradation } \\
\text { undermine the rights of every child / Навколишнє середовище, яке підходить дітям. } \\
\text { Підхід ЮНІСЕФ до кліматичних змін } \\
\text { Основні позиції: } \\
\text { • діти найменш відповідальні за зміни клімату; } \\
\text { - особлива увага до дітей в умовах недостатнього забезпечення; } \\
\text { • забезпечення медичної допомоги. } \\
\text { План пропонованих дій у чотирьох підходах: } \\
\text { • діти є метою стратегії охорони навколишнього середовища; } \\
\text { • діти є агентами змін; } \\
\text { - зменшення викидів і забруднень; } \\
\text { - захистити дітей від впливів. } \\
\text { Пропоновані ЮНІСЕФ ініціативи щодо змін клімату та дітей: } \\
\text { - медцентри, які не шкодять довкіллю; } \\
\text { - школи, які не шкодять довкіллю; } \\
\text { - життєдайне для клімату постачання води; } \\
\text { - припинення забруднення (повітря, ґрунту, води); } \\
\text { - залучення дітей та молоді. }\end{array}$ \\
\hline \multirow[t]{2}{*}{ UNESCO } & Education for sustainable development: a roadmap (2020) \\
\hline & Education in a post-COVID world: nine ideas for public action (2020) \\
\hline USAID & USAID education policy program cycle implementation and operational guidance (2020) \\
\hline $\begin{array}{l}\text { Intergovernmental Panel } \\
\text { on Climate Change (IPCC) }\end{array}$ & Climate Change 2021 The Physical Science Basis (2021) \\
\hline British Council & British Council's Climate4Classrooms \\
\hline $\begin{array}{l}\text { WTO (World Trade } \\
\text { Organization) }\end{array}$ & Trade and Climate Change WTO-UNEP Report (2009) \\
\hline
\end{tabular}

Перелік проаналізованих ресурсів «Освіта про зміну клімату»

\begin{tabular}{|l|l|}
\hline Назва організації & \multicolumn{1}{c|}{ Назва документу } \\
\hline UNESCO & Resources for Education on Climate Change (2016) \\
\cline { 2 - 2 } & Greening Technical and Vocational Education and TrainingA practical guide for institutions (2017) \\
\cline { 2 - 2 } & Skills development and climate change action plans. Enhancing TVET's contribution (2021) \\
\hline
\end{tabular}


Перелік проаналізованих наукових статей та публікацій щодо проблем шкіл, пов'язаних зі змінами клімату

\begin{tabular}{|c|c|}
\hline Автор & Назва, анотація \\
\hline $\begin{array}{l}\text { Perry E. Sheffield, } \\
\text { Simone A. M. } \\
\text { Uijttewaal, } \\
\text { James Stewart, } \\
\text { Maida P. Galvez }\end{array}$ & $\begin{array}{l}\text { Climate Change and Schools: Environmental Hazards and Resiliency } \\
\text { Розкрито особливості регіональних прикладів США щодо проблеми залежності зміни } \\
\text { клімату, потенційних загроз та відновлення життєвих сил для підтримки здорового } \\
\text { середовища у школах (за переліком визначників). }\end{array}$ \\
\hline $\begin{array}{r}\text { Heather } \\
\text { Clark }\end{array}$ & $\begin{array}{l}\text { Climate change and educational attainment in the global tropics } \\
\text { Розглянуто вплив кліматичних особливостей тропічного регіону у зв'язку з кліматичними } \\
\text { змінами (кількість опадів, рівень температури) на досягнення успіхів школярів молодшого } \\
\text { віку в регіоні. }\end{array}$ \\
\hline Heath & $\begin{array}{l}\text { Climate Change May Weaken Children's Education in the Tropics } \\
\text { Проаналізовано впливи кліматичних змін на зниження якості освіти через кризові явища у } \\
\text { зоні тропіків та шляхи вивчення питання залучення дітей до навчання у складних умовах. }\end{array}$ \\
\hline James Roge & $\begin{array}{l}\text { Climate Change Affects Students' Well-Being: Case Study of Extreme Heat in San Joaquin Valley } \\
\text { and Need for Climate-Smart Schools } \\
\text { Запропоновано перелік проблемних питань щодо відповідності матеріально-технічного } \\
\text { забезпечення (будівлі шкіл, витрати фінансування та забезпечення), регіональних } \\
\text { загрозливих умов для здоров'я школярів за глобальної зміни клімату. }\end{array}$ \\
\hline $\begin{array}{c}\text { Francis Nkeiruka } \\
\text { Princess }\end{array}$ & $\begin{array}{l}\text { Climate Change and Implication for Senior Secondary School Financial Accounting Curriculum } \\
\text { Development in Nigeria } \\
\text { Проаналізовано проблему фінансування потреб та їх пріоритетність в умовах кліматичних } \\
\text { змін, впливи останніх на розробку курикулуму професійного напряму старшої школи. }\end{array}$ \\
\hline
\end{tabular}

\section{СПИСОК ВИКОРИСТАНИХ ДЖЕРЕЛ}

Закон України «Про вищу освіту». (2014, 1 липня). https://zakon.rada.gov.ua/laws/show/1556-18

Закон України «Про освіту». (2017, 5 вересня). https:// zakon.rada.gov.ua/laws/show/2145-19

Закон України «Про повну загальну середню освіту». (2020, 16 січня). https://zakon.rada.gov.ua/laws/show/463-20

Кабінет Міністрів України. (2020, 30 вересня). Про деякі питання державних стандартів повноі загальної середньої освіти (898). https:// zakon.rada.gov.ua/laws/show/898-2020-п

Кабінет Міністрів України. (2018, 21 лютого). Про затвердження Державного стандарту початкової освіmи (87). https://zakon.rada.gov.ua/laws/ show/87-2018-п
Президент України. (2021, 16 лютого). Про Консульта тивну раду з питань сприяння розвитку системи загальної середньої освіти (55/2021). https:// zakon.rada.gov.ua/laws/show/55/2021

British Council. (n.d.). https://learnenglish.britishcouncil.org/ European Commission. (2021). Eurydice. https:// eacea.ec.europa.eu/national-policies/eurydice/

Intergovernmental Panel on Climate Change (IPCC). (n.d.). https://www.ipcc.ch/

OECD. (n.d.). https://www.oecd.org/

UNICEF. (n.d.). https://www.unicef.org/

United Nations. (n.d.). https://www.un.org/en/

USAID. (n.d.). https://www.usaid.gov/

World Trade Organizations. (n.d.). https://www.wto.org/

THE START AND END OF THE ACADEMIC YEAR: THE FOREIGN EXPERIENCE

Information of the National Academy of Educational Sciences of Ukraine on request of the Advisory Council to the President of Ukraine for the development of general secondary education

\section{Oleh Topuzov}

DSc in Pedagogy, Professor, Full Member (Academician) of NAES of Ukraine, Vice-President, National Academy of Educational Sciences of Ukraine; Director, Institute of Pedagogy of the National Academy of Educational Sciences of Ukraine, Kyiv, Ukraine Petro Saukh

DSc in Philosophy, Professor, Full Member (Academician) of NAES of Ukraine, Academician Secretary of the Division of Higher Education, National Academy of Educational Sciences of Ukraine, Kyiv, Ukraine Iryna Drach

DSc in Pedagogy, Associate Professor, Acting Director, Institute of Higher Education of the National Academy of Educational Sciences of Ukraine, Kyiv, Ukraine Olena Lokshyna

DSC in Pedagogy, Professor, Corresponding Member of NAES of Ukraine, Head of the Department of Comparative Education, Institute of Pedagogy of the National Academy of Educational Sciences of Ukraine, Kyiv, Ukraine 
Oksana Hlushko

PhD in Pedagogy, Junior Research Fellow of the Department of Comparative Education, Institute of Pedagogy of the National Academy of Educational Sciences of Ukraine, Kyiv, Ukraine Alina Dzhurylo

PhD in Pedagogy, Senior Research Fellow of the Department of Comparative Education, Institute of Pedagogy of the National Academy of Educational Sciences of Ukraine, Kyiv, Ukraine Oksana Maksymenko

PhD in Pedagogy, Research Fellow of the Department of Comparative Education, Institute of Pedagogy of the National Academy of Educational Sciences of Ukraine, Kyiv, Ukraine Nina Nikolska

PhD in Pedagogy, Senior Research Fellow of the Department of Comparative Education, Institute of Pedagogy of the National Academy of Educational Sciences of Ukraine, Kyiv, Ukraine Mariia Debych

DSc in Pedagogy, Associate Professor, Chief Research Fellow of the Department of Quality Assurance in Higher Education, Institute of Higher Education of the National Academy of Educational Sciences of Ukraine, Kyiv, Ukraine

Olha Palamarchuk

PhD in Pedagogy, Senior Research Fellow of the Department of Quality Assurance in Higher Education, Institute of Higher Education of the National Academy of Educational Sciences of Ukraine, Kyiv, Ukraine Kateryna Tryma

PhD in Political Science, Senior Research Fellow of the Department of Interaction between Universities and Society, Institute of Higher Education of the National Academy of Educational Sciences of Ukraine, Kyiv, Ukraine

Abstract. The paper enlightens the problem of defining the start and end of the academic year in general secondary and higher education institutions of foreign countries. The key features of the organisation of time due to the geographical location of countries (in the northern or southern hemisphere), taking into account historical experience and national traditions are given. It is grounded that every higher education institution is autonomous in solving many issues of its activities, in particular for the organisation, start and end of the academic year. The leading trends and a list of basic documents of international organizations on climate change are presented based on the analysis of the last decade special studies and new policies of the foreign countries, international organisations and international bodies on the transformation of time and organizational parameters in general secondary education institutions educational process due to climate change.

Keywords: start of the academic year; end of the academic year; school holidays; educational process; climate change; organisation of time. 